\title{
SATB1 Gene
}

National Cancer Institute

\section{Source}

National Cancer Institute. SATB1 Gene. NCI Thesaurus. Code C74434.

This gene plays a role in DNA binding. 